\title{
DETECTION OF ENTEROTOXIGENIC METHICILLIN RESISTANT STAPHYLOCOCCUS AUREUS IN DAIRY DESSERTS BY MULTIPLEX - PCR
}

\author{
EMAN M. SHAKER
}

Department of Food Hygiene, Faculty of Veterinary Medicine, Sohag University, Egypt.

\section{ABSTRACT}

Received at: 31/3/2015

Accepted: 6/5/2015

\begin{abstract}
The aim of this study is to evaluate the occurrence of methicillin-resistant Staphylococcus aureus (MRSA) in dairy desserts samples and to investigate the antimicrobial resistance and molecular characteristics of these strains using PCR. A total of 120 samples comprising sweetened whipped cream, mehallabeia, ice cream and rice with milk were randomly collected from confectioneries, dairy shops, primitive restaurants and supermarkets in Sohag city, Egypt (30 samples each) and examined for presence of $S$. aureus. The results revealed that $S$. aureus could be detected in $23.3 \%$ of sweetened whipped cream, $6.7 \%$ of mehallabeia, $16.7 \%$ of ice cream and $3.3 \%$ of rice with milk samples. The results of antibiogram testing revealed that the highest percentage $9(7.5 \%)$ of $S$. aureus isolates showed a complete resistance and 4(3.3\%) showed intermediate resistance. However, the lowest percentage $2(1.7 \%)$ of the isolates were sensitive to methicillin. Eight out of nine strains that showed complete resistance using antibiotic sensitivity test identified as MRSA by detection of mecA gene by PCR (five from sweetened whipped cream, one from mehallbeia and two from ice cream samples). Furthermore, some classical enterotoxins gene profile of complete resistant strain were investigated by using M-PCR. The enterotoxins were detected in four strains only, and three different toxinotypes were recorded. The most frequent ones were "sea" gene, and followed by "sed \& seb" from sweetened whipped cream and ice cream samples, while no "sec" gene could be detected from all samples. It is emphasized that the presence of $S$. aureus and their SEs genes in dairy desserts may be regarded as a potential risk for human health.
\end{abstract}

Key words: Staph aureus, Dairy desserts, MRSA, SEs, M-PCR.

\section{INTRODUCTION}

Staphylococcus aureus is involved in a wide variety of humans and animals diseases and its pathogenicity is mainly related to a combination of toxin-mediated virulence, invasive capacity, and antibiotic resistance (Argudin et al., 2010). S. aureus is considered a major foodborne pathogen (Hennekinne et al., 2010). Some strains are able to produce enterotoxins within a foodstuff, causing staphylococcal food-poisoning (SFP), (Argudin et al., 2010). In 2006, S. aureus toxins were responsible for $49 \%$ of 482 human food-borne outbreaks caused by bacterial toxins reported by EU Member States (EFSA, 2007), where $10^{6}$ cells/g of enteroxiginic $S$. aureus strains or more in food is sufficient to produce amount of enterotoxins to cause intoxication (Zinke et al., 2012). S. aureus enterotoxins (SEs) have been divided into 5 serological "classical types" (sea, seb, sec, sed, and see), and among them sea is considered as the main cause of SFP outbreaks in the United States, Japan, France, and UK (Argudin et al., 2010). In the last few years, six new types of SEs (seg, seh, sei, ser, ses, set) and ten staphylococcal-like (SEl) designated as (selj to selv) proteins have been described (Hennekinne et al., 2010).

Milk is a good substrate for $S$. aureus growth and dairy products are common sources of staphylococcal food-poisoning (Scherrer et al., 2004; Morandi et al., 2007). Presence of $S$. aureus on the skin and mucosae of food-producing animals and the frequent association of the pathogen with mastitis, often leads to contamination of milk (Jablonski and Bohach, 1997). Moreover, one third of people are considered as asymptomatic carriers. The organism finds its way into food through hands (infected wounds, skin 
lesions) or by coughing and sneezing (Asperger \& Zangerl 2003). The lack of proper hygienic measures during food processing would also increase the counts of $S$. aureus, especially in manually prepared foods as ready to eat dairy desserts.

There has been increased concern about antibiotic resistant strains of $S$. aureus. Development of resistance has been attributed to the extensive therapeutic use of antimicrobials or to their administration as growth promoters in food animal production (Normanno et al., 2007). Isolates of $S$. aureus are frequently resistant to methicillin and essentially all other $\beta$-lactam antibiotics. An organism with this type of resistance is referred to as methicillin-resistant S. aureus (MRSA) (Lee, 2003). MRSA infections are more difficult to treat with standard antibiotics and thus is more dangerous.

In 2009, the European Food Safety Authority underlined the increasing concern for Public Health represented by the presence of methicillin-resistant $S$. aureus (MRSA) in food producing animals, and recommended that further work should be performed on sampling, detection and quantification of MRSA carriage in both humans and animals, as well as on the contamination of food and the environment (EFSA, 2009). MRSA strains have been isolated in many countries from cows' or small ruminants' milk and various dairy products (Juhasz-Kaszanyitzky et al., 2007; Normanno et al., 2007; Turutoglu et al.; 2006, Ateba et al., 2010; Hata et al., 2010; Spanu et al., 2010; Nam et al., 2011; Vyletělova et al., 2011; Ünal et al., 2012; Medved'ová et al., 2014; Thabet et al., 2014 and Carfora et al., 2015).

The aim of this work was to study the occurrence of $S$. aureus in ready to eat dairy desserts produced locally in Sohag city. The isolates were studied in terms of: (i) methecillin susceptibility for MRSA screening; (ii) Detected MRSA isolates were further genomically characterized; (iii) SEs gene profiles detection by multiplex PCR (M-PCR).

\section{MATERIALS and METHODS}

\section{Sample collection:}

A total of 120 samples of ready to eat dairy desserts including sweetened whipped cream, mehallabeia, ice cream and rice with milk (30 samples each) were collected from confectioneries, dairy shops, primitive restaurants and supermarkets in Sohag city, Egypt.

2. Isolation and identification of $S$. aureus: according to Bennett and Lancette (2001)

All the samples were prepared and enriched on Staphylococci broth for $20 \mathrm{~h}$ at $35^{\circ} \mathrm{C}$ and then inoculated onto Baird Parker Medium (Oxide, Basingstoke, England), and incubated aerobically at $37{ }^{\circ} \mathrm{C}$ for $24 \mathrm{~h}$. The isolates were identified using established microbiological methods which included colony morphology, Gram staining and biochemical testing [catalase, coagulase, D-Nase and sugar fermentation (glucose, sucrose, lactose, mannitol)].

\section{Antimicrobial susceptibility testing :}

Antimicrobial susceptibility was tested by the single diffusion method according to Amita et al. (2008). Sensitivity disc of methicillin (oxacillin) at concentration of $1 \mathrm{ug}$ was used to determine the susceptibility of the isolated Staphylococcus aureus organism (Difco Laboratories and BioMerieux, France).

The antimicrobial susceptibility test was applied according to the guidelines stipulated by National Committee for Clinical Laboratory Standards "NCCLS" (2001). The zones of inhibition (ZI) were measured and recorded after $24 \mathrm{~h}$ of incubation at $35^{\circ}$ $\mathrm{C}$, and the observations were interpreted. The isolates resistant to methicillin (ZI: $10 \mathrm{~mm}$ or less) were regarded as methicillin-resistant Staphylococcus aureus (MRSA), while those with zone of inhibition $(11-12 \mathrm{~mm})$ were regarded as intermediate resistance and $13 \mathrm{~mm}$ or more were termed susceptible.

\section{Molecular characterization:}

\section{a) PCR detection of MRSA:}

Suspected MRSA (positive methicillin resistant of sensitivity test) isolates were further confirmed by molecular method. The detection of mecA gene by PCR assay was performed using primers and protocol described by Jonas et al. (2002).

b) SEs ( $S$. aureus enterotoxins) gene detection: Suspected MRSA isolates were investigated for the presence of genes coding for selected SEs (sea, seb, sec, sed), according to what described by Mehrotra et al. (2000) by using multiplex PCR protocols (MPCR). 
Assiut Vet. Med. J. Vol. 61 No 145 April 2015

Primer sequences of S.aureus used for PCR systems are shown in the following Table:

\begin{tabular}{|c|c|}
\hline Target genes & Oligonucleotide sequence $\left(5^{\prime} \rightarrow 3^{\prime}\right)$ \\
\hline $\operatorname{mecA}(\mathbf{F})$ & 5' TAGAAATGACTGAAC GTCCG '3 \\
\hline $\operatorname{mecA}(\mathbf{R})$ & 5' TTGCGATCA ATGTTACCGTAG ' $\mathbf{3}$ \\
\hline sea $(\mathbf{F})$ & 5' TTGGAAACGGTTAAAACGAA'3 \\
\hline sea (R) & 5' GAACCTTCCCATCAAAAACA ' 3 \\
\hline seb $(\mathbf{F})$ & 5' TCGCATCAAACTGACAAACG ' $\mathbf{3}$ \\
\hline seb (R) & 5' GCGGTACTCTATAAGTGCC ' $\mathbf{3}$ \\
\hline $\sec (\mathbf{F})$ & 5' GACATAAAAGCTAGGAATTT ' 3 \\
\hline $\sec (\mathbf{R})$ & 5' AAATCGGATTAACATTATCC ' $\mathbf{3}$ \\
\hline sed $(F)$ & 5' CTAGTTTGGTAATATCTCCT '3 \\
\hline sed $(R)$ & $\mathbf{5}^{\prime}$ TAATGCTATATCTTATAGGG ' $\mathbf{3}$ \\
\hline
\end{tabular}

RESULTS

Table 1: Incidence and antimicrobial profile of $S$. aureus isolated from dairy desserts samples

\begin{tabular}{cccccccccc}
\hline \multirow{2}{*}{ Samples } & \multicolumn{2}{c}{$\begin{array}{c}\text { Positive biochemical } \\
\text { S. aureus }\end{array}$} & \multicolumn{2}{c}{ Resistant strains } & \multicolumn{2}{c}{$\begin{array}{c}\text { Intermediate } \\
\text { strains }\end{array}$} & \multicolumn{2}{c}{ Sensitive strains } \\
\cline { 2 - 10 } & No./30 & $\%$ & No./30 & $\%$ & No./30 & $\%$ & No./30 & $\%$ \\
\hline $\begin{array}{c}\text { Sweetened whipped } \\
\text { cream }\end{array}$ & 7 & $23.3 \%$ & 5 & 16.7 & 1 & 3.3 & 1 & 3.3 \\
\hline Mehallabeia & 2 & $6.7 \%$ & 1 & 3.3 & 1 & 3.3 & - & - \\
\hline Ice cream & 5 & $16.7 \%$ & 3 & 10 & 1 & 3.3 & 1 & 3.3 \\
\hline Rice with milk & 1 & $3.3 \%$ & - & - & 1 & 3.3 & - & - \\
\hline Total & 15 & $12.5 \%$ & 9 & 7.5 & 4 & 3.3 & 2 & 1.7 \\
\hline
\end{tabular}

Table 2: Frequency distribution and enterotoxins gene profile of MRSA in the examined samples

\begin{tabular}{|c|c|c|c|c|c|c|c|c|}
\hline \multirow{2}{*}{ Samples } & \multicolumn{2}{|c|}{ Positive MRSA } & \multicolumn{6}{|c|}{ SEs gene profile of positive MRSA } \\
\hline & $\begin{array}{c}\text { Sensitivity } \\
\text { test }\end{array}$ & PCR & sea & seb & sec & sed & sea $\& \mathbf{b}$ & Total \\
\hline $\begin{array}{c}\text { Sweetened whipped } \\
\text { cream }\end{array}$ & $5(16.7 \%)$ & $5(16.7 \%)$ & 1 & - & - & - & 1 & 2 \\
\hline Mehallabeia & $1(3.3 \%)$ & $1(3.3 \%)$ & - & - & - & - & - & - \\
\hline Ice cream & $3(10 \%)$ & $2(6.7 \%)$ & 1 & - & - & 1 & - & 2 \\
\hline Rice with milk & - & - & - & - & - & - & - & - \\
\hline Total & $9(7.5 \%)$ & $8(6.7 \%)$ & 2 & - & - & 1 & 1 & 4 \\
\hline
\end{tabular}




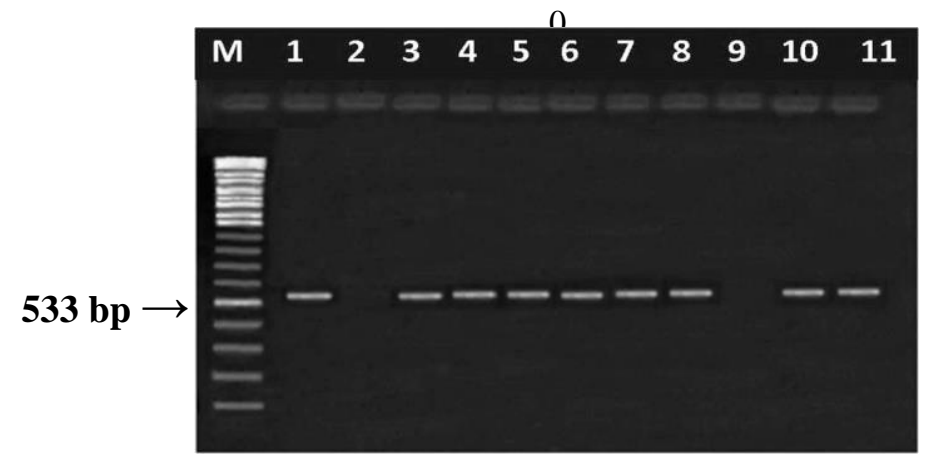

Photo 1: Agarose gel electrophoresis of PCR amplification products of mecA gene for characterization of Methicillin Resistant Staphylococcus aureus (MRSA).

Lane M: 100 bp ladder as molecular size DNA marker. Lane 1: Control positive for mecA gene of S. aureus. Lane 2: Control negative for mecA gene of $S$. aureus. Lanes 3, 4, 5, 6 and 7: Positive S. aureus strains for mecA gene from sweetened whipped cream samples. Lane 8: Positive S. aureus strains for mecA gene from mehallbeia samples. Lanes 10 and 11: Positive S. aureus strains for mecA gene from ice cream samples. Lane 9: Negative $S$. aureus strain for mecA gene ice cream samples.

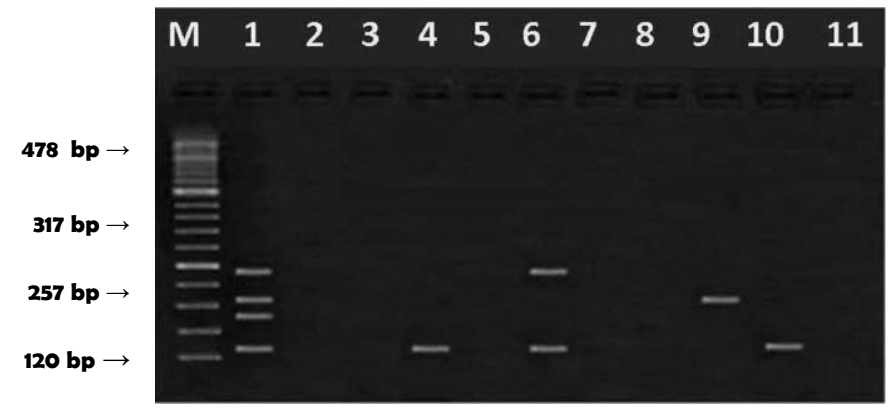

Photo 2: Agarose gel electrophoresis of multiplex PCR of sea (120 bp), seb (478 bp), sec (257bp) and sed (317 bp) enterotoxins genes for MRSA isolates.

Lane M: 100 bp ladder as molecular size DNA marker. Lane 1: Control positive for sea, seb, sec and sed genes. Lane 2: Control negative for sea, seb, sec and sed genes. Lanes 4 \& 10: Positive S.aureus strains for sea gene from sweetened whipped cream \& ice cream samples. Lane 9: Positive S.aureus strain for sed genes from ice cream samples. Lane 6: Positive S.aureus strain for sea and seb genes from sweetened whipped cream samples. Lanes 3, 5, 7, 8 \& 11: Negative S.aureus strains for enterotoxins.

\section{DISCUSSION}

\section{Incidence of $S$. aureus in dairy desserts samples:}

From the current study, it is clear that 15 (12.5\%) out of 26 Staphylococcal spp. isolated from total 120 samples were identified as $S$. aureus which were distributed in, 7(23.3\%), 2(6.7\%), 5(16.7\%) and $1(3.3 \%)$ of sweetened whipped cream, mehallbeia, ice cream and rice with milk examined samples, respectively (Tables $1 \& 2$ ). While a higher percentage $(52 \%)$ of $S$. aureus isolated from dairy desserts was recorded by Ertas et al. (2010). The highest percentage of $S$. aureus were isolated from sweetened whipped cream and ice cream examined samples may be attributed to that these products do not subjected to heat during manufacture in the opposite to mehallbeia and rice with milk examined samples which subjected to heat during manufacture. The high percentage of $S$. aureus in ice cream samples is in agreement with the results obtained by Thabet et al. (2014).

\section{Antimicrobial susceptibility:}

Methicillin-resistant Staphylococcus aureus is an important hospital and community associated pathogen worldwide (Ho et al., 2008). Foods may serve as an important reservoir and source of community-acquired MRSA (Jones et al., 2002). In recent years, MRSA strains have been identified in various foods including bovine milk, ice cream and ready-to-eat foods (Kwon et al., 2006; Fessler et al., 2011; Gucukoglu et al., 2013; Thabet et al., 2014 and Carfora et al., 2015).

The antibiotic resistance profile of MRSA recorded in Tables $1 \& 2$ showed that a highest percentage, 9 (7.5\%) out of 15 isolates of S. aureus, were resistant to methicillin which were recovered from sweetened whipped cream, mehallbeia and ice cream samples in percentages of $16.7,3.3$ and $10 \%$, respectively. While, the intermediate resistance profile was shown in one $(3.3 \%)$ isolate from each of the examined 
dairy desserts products with $3.3 \%$ of total percentage. On the other hand, the sensitive one was the lowest percentage which was represented by $2(1.7 \%)$ and recovered from sweetened whipped cream and ice cream examined samples (one sample of each).

From the present study, it was noted that high percentages of MRSA could be isolated from sweetened whipped cream and ice cream and this poses a potential health risk to consumers. The possible explanation for the significant occurrence of MRSA in these samples may be due to unrestricted and uncontrolled use of antibiotics in animals and farming, besides unsatisfactory health status of cattle herds. Secondly, a greater percentage of contaminations during industry are extensively managed, but they still exist in the contaminated environment (Le Loir et al., 2003; Lowy, 2003; Ono et al., 2008 and Strastkova et al., 2009). In another study, Wang et al. (2014) stated that although MRSA prevalence in retail foods is relatively low, the risk of its transmission through the food chain, especially by uncooked food, cannot be disregarded.

\section{Molecular analysis of suspected MRSA isolates:} $m e c A$ is responsible for resisting to methicillin and other beta lactam antibiotics and is localized in the $S$. aureus chromosome. mecA encodes penicillinbinding protein $2 \mathrm{a}$ (PBP2a), which differs from other penicillin-binding proteins as its active site does not bind methicillin or other beta lactam antibiotics (Lowy, 2003). As such, PBP2a can continue to catalyze the transpeptidation reaction required for peptidoglycan cross-linking, enabling cell wall synthesis in the presence of antibiotics. As a consequence of the inability of PBP $2 \mathrm{a}$ to interact with beta lactammoieties, acquisition of $m e c A$ confers resistance to all beta lactam antibiotics in addition to methicillin (Lowy, 2003 and Sahebnasagh et al., 2011).

Molecular analysis of the suspected MRSA isolates by polymerase chain reaction (PCR) was carried out to detect mecA, which is the gold standard for detecting methicillin-resistance. Eight out of nine suspected MRSA isolates (5 from sweetened whipped cream, 1 from mehallbeia and 2 from ice cream) were positive to the presence of mecA gene (Table $2 \&$ Photo 1). These results go parallel to the results of sensitivity test indicating that most of strains $(88.9 \%)$ showed complete resistance carried mecA gene. The same results were obtained by Thabet et al. (2014). On the other hand, Adesida et al. (2005) stated that PCR assays for detection of MRSA do not always give indisputable results, some isolates have been found to be mecA negative in the PCR, but resistant to methicillin/oxacillin. Also, some isolates have been found to be mecA positive, but susceptible to both methicillin and oxacillin (Olonitola et al., 2007). Finally, measures should be taken to prevent the transmission of MRSA among animals, humans, and the farm environment.

\section{SEs gene profiles detection by multiplex PCR:}

Another troubling aspect of food-associated MRSA is that MRSA frequently contain staphylococcal enterotoxin genes, including genes encoding for enterotoxins most often associated with food poisoning (sea, seb, sec, sed) (EFSA, 2008). Different combinations of staphylococcal enterotoxin genes are associated with different MRSA clones, but the reasons of this association remain unclear. Increased prevalence of MRSA amongst $S$. aureus strains could lead to a higher prevalence of toxinogenic S. aureus (Ferry et al., 2006; Tristan et al., 2007 and EFSA, 2008). Clinically, food poisoning caused by MRSA should be no different than that caused by other S. aureus strains (Weese, 2010).

The analysis of the SEs gene profiles ( sea-sed) was carried out on those suspected MRSA isolates obtained from this study. Results in Table $2 \&$ photo 2 illustrated that only four of suspected MRSA harbor staphylococcal enterotoxins, by which three of them were also harbor mecA gene, these isolates were recovered from two sweetened whipped cream and two ice cream examined samples. These results confirm that enterotoxigenic $S$. aureus can be commonly found in milk and dairy products, as reported in other studies conducted in Northern Italy (Bianchi et al., 2014) and Switzerland (Hummerjohann et al., 2014), adopting a similar approach.

Toxinotypes composed by a single gene were observed in 3 isolates (75\%), two represented by sea gene and one of sed gene, while combination of more than one toxin gene (sea \&seb) occurred in one $(25 \%)$ of isolates, which displaying a remarkable heterogeneity. From these findings, the most frequently SEs genes detected were sea, present in 3 of the isolates. It was found, that sea gene is the most frequent gene among isolates studied by Rall et al. (2008), Ertas et al. (2010) and Medved'ová et al. (2014). However, Normanno et al. (2007); Ote et al. (2011) and Carfora et al. (2015) noticed the majority of strains with sed gene. It is assumed, that sea together with sed are the most frequent agents in SFP outbreaks (Rosengren et al., 2010). Furthermore, sea is predominantly produced by the human strains, so the connection with food contamination during the manufacture is possible (Akineden et al., 2008). Meanwhile, none of the isolates harbored sec gene in this study, the sec was the most predominant gene in other study (Trnčíková et al., 2010; Zigo et al., 2011). This disunity in SEs genes presence among different isolates of $S$. aureus may result from the different ecological niches and geographical origins 
of strains, different cultivation and detection conditions and kinds of samples investigated.

Detection of SEs in sweetened whipped cream and ice cream examined samples may support the fact that said If food is cooked properly, MRSA cells will be killed however, as with enterotoxigenic MRSA strains, under condition of temperature abuse MRSA cells could grow in food produce heat-stable enterotoxins and cause foodborne intoxication.

In conclusion, the presence of enterotoxigenic $S$. aureus in dairy desserts showed that consumption of ready to eat dairy desserts might be a potential risk of food poisoning. Therefore, consumers should avoid the consumption of unpasteurized dairy products. Further surveillance on prevalence of $S$. aureus as well as emerging antimicrobial resistance is required to recognize foods that may represent health risk and to ensure the effective treatment of foodborne infections.

\section{REFERENCES}

Adesida, S.A.; Bocleas, H.; Babajide, B.; Kehinde, A.; Saijders, S.; Van Leeuwen, W.; Coker, A., Verbrugh, H. and Van Belkum, A. (2005): Major epidemic clones of Staphylococcus aureus in Nigeria. Microb Drug Resist., 11: 115-121.

Akineden, Ö.; Hassan, A.A.; Schnieder, E. and Usleber, E. (2008): Enterotoxinogenic properties of $S$. aureus isolated from goats' milk cheese. International Journal of Food Microbiology, 124: 211-216.

Amita, J.; Astha, A. and Raj, K. (2008): Cefoxitin disc diffusion test for detection of methicillin resistant staphylococci. J. Med. Microbiol. 57: 957-961.

Argudin, M.A.; Mendoza, M.C. and Rodicio, M.R. (2010): Food poisoning and Staphylococcus aureus enterotoxins. Toxins, 2: 1751-1773.

Asperger, H. and Zangerl, P. (2003): Staphylococcus aureus. In: (eds.: Roginski H, Fuquay, JW, Fox PF) Encyclopaedia of Dairy Sciences. Academic Press, San Diego, pp. 2563-2569.

Ateba, C.N.; Mbewe, M.; Moneoang, M.S. and Bezuidenhout, C.C. (2010): Antibioticresistant Staphylococcus aureus isolated from milk in the Mafikeng Area, North West province, South Africa. South Africa J. Science, 106:1-6.

Bennett, R.W. and Lancette, G.A. (2001): Staphylococcus aureus. In: FDA Bacteriological 1 Manual .8th Ed. Gaither sburg, MD, AOAC International: 12 .

Bianchi, D.M.; Gallina, S.; Bellio, A.; Chiesa, F.; Civera, T. and Decastelli, L. (2014): Enterotoxin gene profiles of Staphylococcus aureus isolated from milk and dairy products in Italy. Letters in Applied Microbiology, 58: 190-196.

Carfora, V.; Caprioli, A.; Marri, N.; Sagrafoli, D.; Boselli, C.; Giacinti, G.; Giangolini, G.; Sorbara, L.; Dottarelli, S.; Battisti, A. and Amatiste, S. (2015): Enterotoxin genes, enterotoxin production, and methicillin resistance in Staphylococcus aureus isolated from milk and dairy products in Central Italy. International Dairy Journal 42: 12-15.

EFSA (European Food Safety Authority) (2007): The community summary report on trends and sources of zoonoses, Zoonotic Agents, Antimicrobial Resistance and Foodborne Outbreaks in the European Union in 2006. EFSA J., 130:2-352.

EFSA (European Food Safety Authority) (2008): Foodborne antimicrobial resistance as a biological hazard Scientific Opinion of the Panel on Biological Hazards Public consultation (Question No EFSA-Q-2007089). EFSA J., 765, 2-87.

EFSA (European Food Safety Authority) (2009): Assessment of the Public Health significance of methicillin resistant Staphylococcus aureus (MRSA) in animals and foods. Scientific Opinion of the Panel on Biological Hazards (Question No EFSA-Q-2008-300). EFSA J., 993:1-73.

Ertas, N.; Gonulalan, Z.; Yildirim, Y. and Kum, E. (2010): Detection of S. aureus enterotoxins in sheep cheese and dairy desserts by multiplex PCR technique. Int. J. Food Microbiol, 142: 74-77.

Ferry, T.; Bes, M.; Dauwalder, O.; Meugnier, H.; Lina, G.; Forey, F.; Vandenesch, F. and Etienne, J. (2006): Toxin gene content of the Lyon methicillin-resistant Staphylococcus aureus clone compared with other pandemic clones. J. Clin. Microbiol 44: 2642-2644.

Fessler, A.T.; Kadlec, K. and Hasse, I.M. (2011): Characterization of methicillin-resistant Staphylococcus aureus isolates from food and food products of poultry origin in Germany. Appl Environ Microbiol., 77: 7151-7157.

Gucukoglu, A.; Cadirci, O.; Terzi, G.; Kevenk, T.O. and Alisarli, M. (2013): Determination of enterotoxigenic and methicillin resistant Staphylococcus aureus in ice cream. J. food Sci., 78: 738-741.

Hata, E.; Katsuda, K.; Kobayashi, H.; Uchida, I.; Tanaka, K. and Eguchi, M. (2010): Genetic variation among Staphylococcus aureus strains from bovine milk and their relevance to methicillin-resistant isolates from humans. J. Clin. Microbiol, 48: 2130-2139.

Hennekinne, J.A.; Ostyn, A.; Guillier, F.; Herbin, S.; Prufer, A.L. and Dragacci, S. (2010): How should staphylococcal food poisoning 
outbreaks be characterized?. Toxins, 2: 2106-2116.

Ho, P.L.; Chuang, S.K. and Choi, Y.F. (2008): Community-associated methicillin-resistant and methicillin-sensitive Staphylococcus aureus. Skin and soft tissue infections in Hong Kong. Diagn. Microbiol. Infect. Dis., 61: 245-250.

Hummerjohann, J.; Naskova, J.; Baumgartner, A. and Graber, H.U. (2014): Enterotoxin producing Staphylococcus aureus genotype B as a major contaminant in Swiss raw milk cheese. Journal of Dairy Science, 97: 1305-1312.

Jablonski, L.M. and Bohach, G.A. (1997): Staphylococcus aureus. In: (eds.: Doyle MP, Beuchat LR, Montville TD) Food Microbiology: fundamentals and frontiers. ASM Press, Washington, D.C., USA, pp. 353-375.

Jonas, D.; Speck, M.; Daschner, F. and Grundmann, H. (2002): Rapid PCR-Based Identification of Methicillin-Resistant Staphylococcus aureus from Screening Swabs. J. Clin. Microbiol., 40(5): 1821-1823.

Jones, T.F.; Kellum, M.E.; Porter, S.S.; Bell, M. and Schaffner, W. (2002): An outbreak of community-acquired foodborne illness caused by methicillin-resistant Staphylococcus aureus. Emerg Infect Dis., 8:82-84.

Juhasz-Kaszanyitzky, E.; Janosi, S.; Somogyi, P.; Dan, A.; Van der Graafvan Bloois, L.; Van Duijkeren, E. and Wagenaar, J.A. (2007): MRSA transmission between cows and humans. Emerg Infect Dis., 13: 630-632.

Kwon, N.H.; Park, K.T.; Jung, W.K.; Youn, H.Y.; Lee, Y.; Kim, S.H.; Bae, W.; Lim, J.Y.; Kim, J.Y.; Kim, J.M.; Hong, S.K. and Park, Y.H. (2006): Characteristics of methicillin resistant Staphylococcus aureus isolated from chicken meat and hospitalized dogs in Korea and their epidemiological relatedness. Vet. Microbiol., 117 (24): 304-312.

Le Loir, Y.; Baron, F. and Gautier, M. (2003): Staphylococcus aureus and food poisoning. Genet Mol Res., 2 (1): 63-76.

Lee, J.H. (2003): Methicillin (Oxacillin)-resistant Staphylococcus aureus strains isolated from major food animals and their potential transmission to humans. Appl Environ Microbiol, 69: 648-649.

Lowy, F.D. (2003): Antimicrobial resistance: the example of Staphylococcus aureus. J. Clin. Invest., 111(9): 1265-1273.

Medved'ová, A.; Studeničová, A.; Valik, L. and Horváthová, Z. (2014): Prevalence and growth dynamics of enterotoxinogenic Staphylococcus aureus isolates in Slovakian dairy products. Czech J. Food Sci., 32: $337-341$.
Mehrotra, M.; Wang, G. and Johnson, W. (2000): Multiplex PCR for detection of genes for Staphylococcus aureus enterotoxins, exfoliative toxins, toxic shock syndrome toxin 1, and methicillin resistance. J. Clin. Microbiol., 38: 1032-1035.

Morandi, S.; Brasca, M.; Lodi, R.; Cremonesi, P. and Castiglioni, B. (2007): Detection of classical enterotoxins and identification of enterotoxin genes in Staphylococcus aureus from milk and dairy products. Vet. Microbiol, 124: 66-72.

Nam, H.M.; Lee, A.L.; Jung, S.C.; Kim, M.N.; Jang, G.C.; Wee, S.H. and Lim, S.K. (2011): Antimicrobial susceptibility of Staphylococcus aureus and characterization of methicillinresistant Staphylococcus aureus isolated from bovine mastitis in Korea. Foodborne Pathog Dis, 8: 231-238.

National Committee for Clinical Laboratory Standards "NCCLS" (2001): Performance standards for antimicrobial susceptibility testing. Supplement M100-S11. Villanova, PA, USA.

Normanno, G.; Corrente, M.; Salandra, G.; Dambrosio, A.; Quaglia, N.C.; Parisi, A.; Santagada, G.; Firinu, A.; Crisetti, E. and Celano, G.V. (2007): Methicillin resistant Staphylococcus aureus (MRSA) in foods of animal origin product in Italy. Int. J. Food Microbiol, 117: 219-222.

Olonitola, O.S; Olayinka, B.O. and Onaolapo, J.A. (2007): Absence of mecA in MRSA isolated from non hospital source in Zaria, Nigeria Intern. J. Nat. App. Sci., 13: 160-164.

Ono, H.K.; Gautier, M. and Tomasz, A. (2008): Identification and characterization of two novel staphylococcal enterotoxins, types $\mathrm{S}$ and T. Infect. Immun., 76: 4999-5005.

Ote, I.; Taminiau, B.; Duprez, J.N. and Mainil, J.G. (2011): Genotypic characterization by PCR of $S$. aureus isolates with bovine mastitis. Veterinary Microbiology, 153: 285-292.

Rall, V.L.M.; Vierira, F.P.; Rall, R.; Vietis, R.L.; Fernandes, A.; Candeias, J.M.G. and Araújo, J.P. (2008): PCR detection of staphylococcal enterotoxin genes in $S$. aureus strains isolated from raw and pasteurized milk. Veterinary Microbiology, 132: 408-413.

Rosengren, A.; Fabricius, A.; Guss, B.; Sylvén, S. and Lindqvist, R. (2010): Occurence of foodborne pathogens and characterizations of $S$. aureus in cheese produced in farm-dairies. International Journal of Food Microbiology, 144: 263-269.

Sahebnasagh, R.; Saderi, H. and Owlia, P. (2011): Detection of methicillin-resistant Staphylococcus aureus strains from clinical samples in Tehran by detection of the mecA and $n u c$ genes. The First Iranian International 
Congress of Medical Bacteriology; 4-7 September; Tabriz, Iran. 2011, pp. 195.

Scherrer, D.; Corti, S.; Muehlherr, J.E.; Zweifel, C. and Stephan, R. (2004): Phenotypic and genotypic characteristics of Staphylococcus aureus isolates from raw bulk-tank milk samples of goats and sheep. Vet. Microbiol. 101: 101-107.

Spanu, V.; Virdis, S.; Scarano, C.; Cossu, F.; De Santis, E. and Cosseddu, A. (2010): Antibiotic resistance assessment in $S$. aureus strains isolated from raw sheep's milk cheese. Vet. Res. Commun, 34: 87-90.

Strastkova, Z.; Karpiskova, S. and Karpiskova, R. (2009): Occurrence of methicillin-resistant strains of Staphylococcus aureus at goat breeding farm. Vet. Med., 54: 419-42.

Thabet, S.S.; Amin, M.M.; Elsherif, W.M.A.; Hasan, A.M. and Wahba, N.M. (2014): Phenotypic and Genotypic Methicillin resistant Staphylococcus aureus (MRSA) isolated from raw milk and some milk products. Glob. J. Agric. Food Safety Sci., 1 (1): 317-325.

Tristan, A.; Ferry, T.; Durand, G.; Dauwalder, O.; Bes, M.; Lina, G.; Vandenesch, F. and Etienne, J. (2007): Virulence determinants in community and hospital methicillin-resistant Staphylococcus aureus. J. Hosp Infect 65: 105-109.

Trnčíková, T.; Piskernik, S.; Kaclíková, E.; Možina, S.S.; Kuchta, T. and Jeršek, B. (2010): Characterization of $S$. aureus strains isolated from food produced in Slovakia and Slovenia with regard to the presence of genes encoding for enterotoxins. Journal of Nutrition and Food Research, 49: 215-220.
Turutoglu, H.; Ercelik, S. and Ozturk, D. (2006): Antibiotic resistance of Staphylococcus aureus and coagulase-negative Staphylococci isolated from bovine mastitis. Bull Vet Res Inst Pulawy, 50:41.

Ünal, N.; Askar, Ş.; Macun, H.C.; Sakarya, F.; Altun, B. and Ylldırım, M. (2012): PantonValentine leukocidin and some exotoxins of Staphylococcus aureus and antimicrobial susceptibility profiles of Staphylococci isolated from milks of small ruminants. Trop Anim Health Prod, 44:573-579.

Vyletělova, M.; Hanuš, O.; Karpíšková, R. and Štástková, Z. (2011): Occurrence and antimicrobial sensitivity in Staphylococci isolated from goat, sheep and cow's milk. Acta Universitatis Agric Silvic Mendelianae Brunensis 59: 209-213.

Wang, X.; Li, G.; Xia, X.; Yang, B.; Xi, M. and Meng, J. (2014): Antimicrobial Susceptibility and Molecular Typing of Methicillin-Resistant Staphylococcus aureus in Retail Foods in Shaanxi, China. Foodborne Pathogens and Disease, 11(4): 281-286.

Weese, J.S. (2010): Methicillin-resistant Staphylococcus aureus in animals. ILAR J 51: 233-244.

Zigo, F.; Vasil', M.; Kadáši, M.; Elečko, J. and Farkašová, Z. (2011): Bacteria Staphylococcus spp. isolated from mastitis of sheep and their enterotoxigenic properties. Potravinararstvo, 5: 70-72

Zinke, C.; Winter, M.; Mohr, E. and Krömker, V. (2012): Occurrence of Methicillin-Resistant Staphylococcus aureus in Cheese Produced in German Farm-Dairies. Advances in Microbiology, 2: 629-633.

\section{الكثف عن المكور العنقودى الذهبى المفرز للسموم والمقاوم للمزيسيللين فى الحلاوى اللبنية باستخدام إختبار البلملرة المتعدد المتسلسل \\ إيعان مختار شاكر}

Assiut University Email: $\underline{w w w . a u n . e d u . e g}$

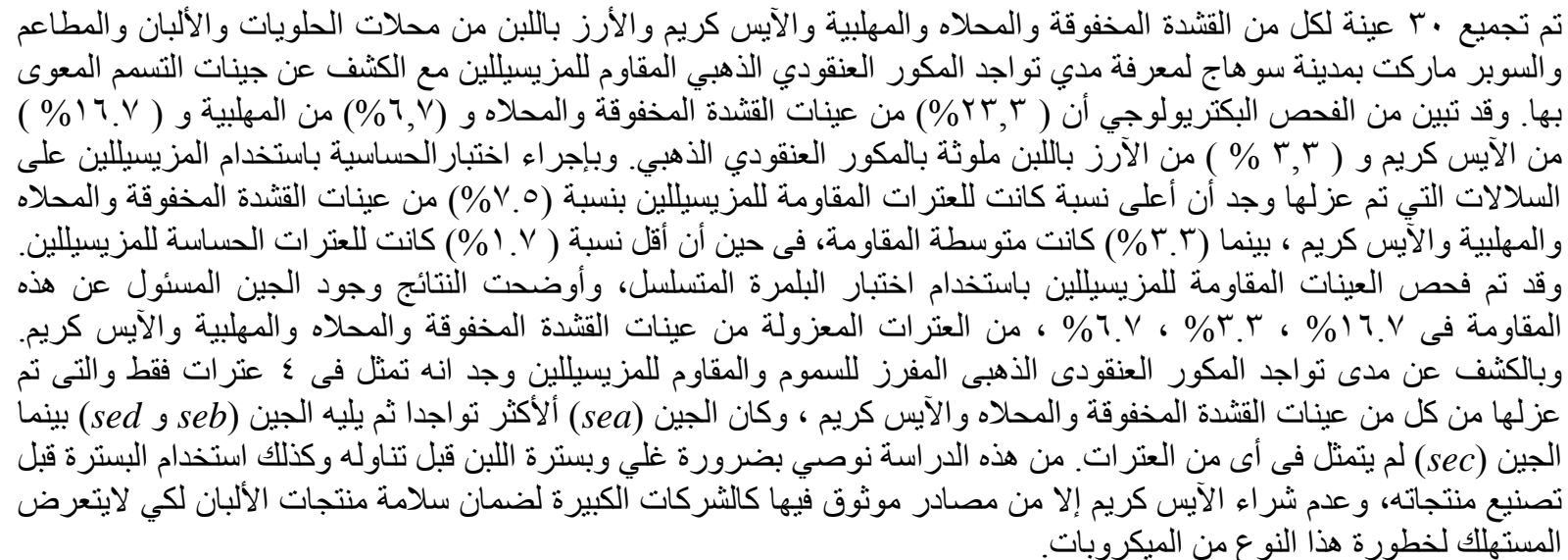

